\title{
Badania nad stereotypem Chińczyka, czyli jak Polacy postrzegają przedstawicieli Państwa Środka
}

\section{Znaczenie stereotypu w stosunkach międzynarodowych}

Źródłosłów słowa „stereotyp” wywodzi się z języka greckiego i składa z dwóch członów: stereós - stężały, sztywny, masywny; typos - odcisk, wzorzec. Po raz pierwszy określenia „stereotyp” użyto w roku 1797, a dokonał tego Firmin Didot, określając wymyślony przez siebie system drukowania z całej metalowej płyty (sztywnej matrycy) zamiast złożonych, ruchomych czcionek ${ }^{1}$.

W naukach humanistycznych jako pierwszy słowa „stereotyp” użył Walter Lippmann w książce Public Opinion, wydanej w 1922 roku. Według Lippmanna, stereotypy to po prostu „obrazy w naszej głowie” (pictures in our head). Lippmann scharakteryzował stereotypy jako reakcje docierające do nas z zewnątrz i przetworzone $\mathrm{w}$ umyśle, a niezbędne do funkcjonowania w otaczającym nas świecie, gdzie: „Nie ma ani czasu, ani okazji do bliższego poznania. Zamiast tego chwytamy jakiś rys, który sygnalizuje nam dobrze

\footnotetext{
* Magister, doktorantka, Uniwersytet Łódzki, Wydział Studiów Międzynarodowych i Politologicznych, Zakład Azji Wschodniej.

1 IT Media, Firmin Didot, http://www.mojefonty.pl/firmin-didot/ [dostęp: 20.01.2013].
} 
znany typ i resztę obrazu wypełniamy za pomocą stereotypów, które nosimy w swoich głowach"2.

Lippmann dokonał także rozdzielenia stereotypów na autostereotypy, czyli odnoszące się do obrazu własnej grupy zakodowanego w naszym umyśle (podmiot i przedmiot autostereotypu jest ten sam), i heterostereotypy związane z postrzeganiem grupy obcej (podmiot postrzegający i przedmiot postrzegany nie są te same).

Tę dwudzielność stereotypów (obraz grupy własnej jest zawsze nacechowany dodatnio, zaś grupy obcej obciążony wieloma uwarunkowaniami, takimi jak np. relacje obecne oraz historia) szczególnie widać w stosunkach międzynarodowych. Jan Błuszkowski w swojej pracy Stereotypy a tożsamość narodowa wskazał, iż stereotypy

pełnią więc ważne funkcje polityczne związane z kształtowaniem stosunków międzynarodowych - służą artykulacji interesów grup narodowych i etnicznych, są instrumentalnie wykorzystywane w celach propagandowych i manipulacyjnych, kanalizują agresję, stanowią też rodzaj uzasadnienia słuszności przyjmowanych strategii działań wspólnot etniczno-politycznych w stosunkach międzynarodowych ${ }^{3}$.

Nietrudno zauważyć, iż stereotypy są podstawą uprzedzeń i jedną z przyczyn konfliktów. Wykorzystuje się je w polityce do kreowania określonych celów narodowych, budowania napięcia między państwami, podkreślania istotności problemów, pojawiających się we wzajemnych relacjach, wyjaśniania ich braku.

Po usłyszeniu słowa „Niemiec”, „Rosjanin”, „Szkot” itp. stereotyp uruchamia w naszych umysłach pewne projekcje obrazów, dzięki którym formułujemy swoje sądy o danej osobie, jeszcze zanim nawiążemy z nią bezpośredni kontakt, a to jak postrzegamy dany naród, nim nawiążemy bliższe relacje z jego przedstawicielem, rzutuje na nasze nastawienie i podejście do niego. Z kolei stereotypy utrwalone dzięki wielowiekowym kontaktom między narodami są uznawane za pewnik, a ich ewentualna zmiana jest procesem bardzo długim i trudnym.

Jan Berting i Christiane Villain-Gandossi skonstruowali definicję stereotypu, która bardzo dobrze wskazuje role, jakie pełni on w naszym życiu. Według wspomnianych autorów stereotyp:

- jest bardzo istotnym składnikiem, który integruje społeczeństwo, a jego ślad odnaleźć można zarówno w motywach działań społecznych, jak i propagandzie politycznej oraz wyznawanej ideologii;

W. Lippmann, Public Opinion, New York 1922, s. 79.

J. Błuszkowski, Stereotypy a tożsamość narodowa, Warszawa 2005, s. 27. 
- pełni rolę sądu negatywnego lub pozytywnego, który oparty jest na przekonaniu grupy;

- ma społeczną genezę; jest nam przekazywany od najmłodszych lat, począwszy od rodziny, poprzez proces socjalizacji i uczestnictwa w grupie, co warto podkreślić - bez względu na jej osobiste doświadczenia;

- jest niemożliwy do oddzielenia od emocji - są ze sobą powiązane; stereotyp bywa nacechowany negatywnie bądź pozytywnie;

- zazwyczaj nie opiera się na prawdzie lub odpowiada jej tylko częściowo, jednak przez członków danej grupy uznawany jest za w pełni prawdziwy;

- w związku z uniezależnieniem od faktycznych doświadczeń członków grupy, jest trwały i niezmienny w długim okresie czasu4

\section{Chińczycy w badaniu CBOS}

Centrum Badania Opinii Społecznej (w skrócie CBOS) już ponad dwadzieścia lat prowadzi badania dotyczące postrzegania przez Polaków innych narodów. Patrząc na wyniki komunikatu nr 53/2016 z kwietnia 2016 roku, można zobaczyć i porównać nastawienia Polaków do innych narodów, a wśród nich i do Chin oraz Chińczyków, których stereotypem zajmę się w tym artykule.

Komunikat 53/2016 prezentuje wyniki badan „Aktualne problemy i wydarzenia" (310), przeprowadzonych w dniach 2-9 marca 2016 roku metodą wywiadów bezpośrednich (tzw. face to face) wspomaganych komputerowo (CAPI - Computer Assisted Personal Interview). Badaniem objęto reprezentatywną próbę losową dorosłych mieszkańców Polski (1034 osoby).

Pierwsze miejsce najbardziej lubianego narodu przypada Czechom, do których sympatię zadeklarowało aż 50\% respondentów. Na drugim miejscu pod względem sympatii uplasowali się Włosi z wynikiem 49\%. Listę zamykają Romowie i Arabowie, cieszący się najmniejszą sympatią Polaków. I tak Romowie zebrali tylko $11 \%$ pozytywnych opinii, zaś Arabowie $8 \%$. Co zaś do Chińczyków to zajęli osiemnaste miejsce (na 27) - zaledwie 25\% respondentów wyraziło swoją sympatię dla nich, 35\% wskazało na swoją obojętność, 28\% zadeklarowało niechęć, zaś $11 \%$ nie miało zdania w tej kwestii. Średnia dla Chińczyków wynosi $-0,10$, co wskazuje na stosunek obojętny z niewielką przewagą niechęci do tego narodu ${ }^{5}$.

4 J. Berting, Ch. Villain-Gandossi, Rola i znaczenie stereotypów narodowych $w$ stosunkach międzynarodowych: podejście interdyscyplinarne, [w:] Narody i stereotypy, T. Walas (red.), Kraków 1995, s. 14-15.

5 Stosunek Polaków do innych narodów, Komunikat z badań, CBOS, nr 53, Warszawa 2016. 
Katarzyna Grabowska

Tabela 1. Stosunek Polaków do innych narodów, CBOS styczeń 2016

\begin{tabular}{|c|c|c|c|c|c|}
\hline \multirow{2}{*}{$\begin{array}{c}\text { Narody } \\
\text { według } \\
\text { malejącego } \\
\text { stopnia } \\
\text { sympatii }\end{array}$} & \multicolumn{5}{|c|}{ Jak określił(a) by Pan(i) swój stosunek do innych narodów? (\%) } \\
\hline & Sympatia & Obojętność & Niechęć & $\begin{array}{c}\text { Trudno } \\
\text { powiedzieć }\end{array}$ & Średnia \\
\hline Czesi & 50 & 30 & 13 & 7 & 0,72 \\
\hline Włosi & 49 & 31 & 13 & 7 & 0,74 \\
\hline Słowacy & 48 & 31 & 13 & 8 & 0,75 \\
\hline Anglicy & 47 & 30 & 16 & 7 & 0,61 \\
\hline Hiszpanie & 46 & 31 & 14 & 9 & 0,64 \\
\hline Amerykanie & 46 & 30 & 17 & 7 & 0,58 \\
\hline Węgrzy & 45 & 30 & 17 & 9 & 0,63 \\
\hline Francuzi & 43 & 32 & 18 & 7 & 0,53 \\
\hline Holendrzy & 41 & 32 & 16 & 11 & 0,54 \\
\hline Szwedzi & 40 & 32 & 16 & 12 & 0,52 \\
\hline Austriacy & 38 & 34 & 17 & 11 & 0,45 \\
\hline Japończycy & 38 & 30 & 20 & 12 & 0,40 \\
\hline Niemcy & 37 & 32 & 26 & 5 & 0,20 \\
\hline Grecy & 34 & 31 & 25 & 10 & 0,24 \\
\hline Litwini & 31 & 31 & 27 & 11 & 0,13 \\
\hline Ukraińcy & 27 & 33 & 34 & 6 & $-0,18$ \\
\hline Bułgarzy & 26 & 38 & 26 & 11 & 0,01 \\
\hline Chińczycy & 25 & 35 & 28 & 11 & $-0,10$ \\
\hline Białorusini & 25 & 32 & 32 & 11 & $-0,12$ \\
\hline Żydzi & 23 & 31 & 37 & 9 & $-0,32$ \\
\hline Wietnamczycy & 21 & 33 & 32 & 14 & $-0,22$ \\
\hline Serbowie & 20 & 30 & 35 & 15 & $-0,32$ \\
\hline Rosjanie & 20 & 24 & 50 & 6 & $-0,71$ \\
\hline Turcy & 16 & 28 & 45 & 11 & $-0,63$ \\
\hline Rumuni & 15 & 29 & 47 & 9 & $-0,73$ \\
\hline Romowie & 11 & 17 & 67 & 5 & $-1,33$ \\
\hline Arabowie & 8 & 16 & 67 & 9 & $-1,51$ \\
\hline
\end{tabular}

Źródło: CBOS, Stosunek Polaków do innych narodów, Komunikat z badań, CBOS, nr 53, Warszawa 2016. 
Śledząc wyniki badań CBOS dotyczące zmiany sympatii do poszczególnych narodów, można zauważyć, iż w latach 1993-1997 brak badań nad sympatią dla Chińczyków. Rok 1998 przynosi wynik 21 punktów. Niewielki spadek sympatii da się odnotować w 1999 roku, a ponowny wzrost w latach 2001-2002. Rok 2003 przyniósł spadek sympatii, a kolejne dwa lata pogłębiły tę tendencję. Od 2006 roku nastąpił wzrost sympatii do Chińczyków z lekkim zachwianiem w roku 2009. Po 2009 roku utrzymywała się tendencja wzrastająca, która jednak w badaniu z 2013 roku wykazała spadek sympatii do $27 \%$. Kolejne lata to istna huśtawka. Dalszy spadek do $25 \%$ w 2014 roku, wzrost do 27\% w 2015 i ponowny spadek do 25\% w 2016.

Tabela 2. Zmiany sympatii do Chińczyków

\begin{tabular}{|c|c|c|c|c|c|c|c|c|c|c|c|c|c|c|c|c|c|c|c|}
\hline Rok & $\mathbf{9 8}$ & $\mathbf{9 9}$ & $\mathbf{0 0}$ & $\mathbf{0 1}$ & $\mathbf{0 2}$ & $\mathbf{0 3}$ & $\mathbf{0 4}$ & $\mathbf{0 5}$ & $\mathbf{0 6}$ & $\mathbf{0 7}$ & $\mathbf{0 8}$ & $\mathbf{0 9}$ & $\mathbf{1 0}$ & $\mathbf{1 1}$ & $\mathbf{1 2}$ & $\mathbf{1 3}$ & $\mathbf{1 4}$ & $\mathbf{1 5}$ & $\mathbf{1 6}$ \\
\hline$\%$ & 21 & 19 & - & 22 & 26 & 22 & 20 & 16 & 18 & 22 & 31 & - & 20 & 31 & 32 & 27 & 25 & 27 & 25 \\
\hline
\end{tabular}

Źródło: CBOS, Stosunek Polaków do innych narodów, Komunikat z badań, CBOS, nr 53, Warszawa 2016.

Jeśli chodzi o antypatię wobec Chińczyków to najgorszy wynik zanotowano w roku 2005, kiedy prawie połowa ankietowanych (47\%) określiła swój stosunek do Chińczyków jako niechęć. Najlepszy był rok 2011, gdy tylko 26\% pytanych osób zadeklarowało antypatię. Rok 2012 to niewielki wzrost niechęci do poziomu 31\%, zaś rok 2013 przyniósł wzrost niechęci o jeden procent w stosunku do roku poprzedniego. Rok 2014 przyniósł dalszy wzrost antypatii do 36\%, jednak w roku 2015 odnotowano spadek niechęci do 29\% i kolejny spadek o jeden punkt w roku $2016^{6}$.

Tabela 3. Zmiany niechęci do Chińczyków

\begin{tabular}{|c|c|c|c|c|c|c|c|c|c|c|c|c|c|c|c|c|c|c|c|}
\hline Rok & $\mathbf{9 8}$ & $\mathbf{9 9}$ & $\mathbf{0 0}$ & $\mathbf{0 1}$ & $\mathbf{0 2}$ & $\mathbf{0 3}$ & $\mathbf{0 4}$ & $\mathbf{0 5}$ & $\mathbf{0 6}$ & $\mathbf{0 7}$ & $\mathbf{0 8}$ & $\mathbf{0 9}$ & $\mathbf{1 0}$ & $\mathbf{1 1}$ & $\mathbf{1 2}$ & $\mathbf{1 3}$ & $\mathbf{1 4}$ & $\mathbf{1 5}$ & $\mathbf{1 6}$ \\
\hline$\%$ & 36 & 37 & - & 22 & 26 & 39 & 37 & 47 & 43 & 38 & 30 & - & 27 & 26 & 31 & 32 & 36 & 29 & 28 \\
\hline
\end{tabular}

Źródło: CBOS, Stosunek Polaków do innych narodów, Komunikat z badań, CBOS, nr 53, Warszawa 2016.

\section{Chińczycy w badaniach Jana Błuszkowskiego}

Jan Błuszkowski w swojej pracy zatytułowanej Stereotypy narodowe w świadomości Polaków. Studium socjologiczno-politologiczne zamieścił wyniki własnych badań przeprowadzonych w latach 1999-2002, a dotyczących autostereotypów

\footnotetext{
6 Ibidem.
} 
i heterostereotypów funkcjonujących w społeczeństwie polskim. Badania dotyczyły zatem tego, jak Polacy postrzegają samych siebie i jak postrzegają inne narody.

W zestawieniu cech najczęściej przypisywanych poszczególnym narodom respondenci wymieniali jako charakterystyczne dla Chińczyków: pracowitość (33,7\%), ubóstwo $(21,1 \%)$, fanatyzm $(11,7 \%)^{7}$.

Pomiar dystansu społecznego Polaków wobec innych narodów, oparty na treściach emocjonalnych, dotyczy trzech wymiarów: mikrospołecznego, makrospołecznego i partycypacyjnego. W wymiarze mikrospołecznym wyniki badań profesora Błuszkowskiego ukazują, iż Polacy cechują się pewnym dystansem do Chińczyków w odniesieniu do kontaktów zawodowych, sąsiedzkich i przyjacielskich, a dystans ten wzrasta, gdy chodzi o kontakty rodzinne ${ }^{8}$.

Tabela 4. Dystans społeczny Polaków do Chińczyków - wymiar mikrospołeczny

\begin{tabular}{|c|c|c|c|c|}
\hline \multicolumn{4}{|c|}{ Kontinuum wymiaru mikrospołecznego } & $\begin{array}{c}\text { Suma } \\
\text { odrzuceń }\end{array}$ \\
\hline $\begin{array}{c}\text { Stopień } 1 \\
- \text { kontakty }\end{array}$ & $\begin{array}{c}\text { Stopień } 2 \\
- \text { kontakty } \\
\text { pracownicze }\end{array}$ & $\begin{array}{c}\text { Stopień 3 } \\
- \text { kontakty } \\
\text { sąsiedzkie }\end{array}$ & $\begin{array}{c}\text { Stopień } 4 \\
- \text { kontakty } \\
\text { rodzinne }\end{array}$ & \\
\hline 110 & 127 & 135 & 511 & 883 \\
\hline
\end{tabular}

Źródło: J. Błuszkowski, Stereotypy narodowe w świadomości Polaków: studium socjologiczno-politologiczne, Warszawa 2003, s. 215.

W wymiarze makrospołecznym widać, iż Polacy nie są przeciwni odwiedzaniu Polski przez Chińczyków, jednak niechęć wzrasta, gdy pojawia się kwestia podejmowania przez nich pracy, osiedlania się w Polsce i otrzymywania obywatelstwa polskiego 9 .

Tabela 5. Dystans społeczny Polaków do Chińczyków - wymiar makrospołeczny

\begin{tabular}{|c|c|c|c|c|}
\hline \multicolumn{4}{|c|}{$\begin{array}{l}\text { Kontinuum wymiaru makrospołecznego } \\
\text { Liczba odrzuceń kontaktu danego stopnia }\end{array}$} & $\begin{array}{l}\text { Suma } \\
\text { odrzuceń }\end{array}$ \\
\hline $\begin{array}{c}\text { Stopień } 1 \\
\text { - odwiedzanie } \\
\text { Polski w charakterze } \\
\text { turystów }\end{array}$ & $\begin{array}{c}\text { Stopień } 2 \\
\text { - podejmowanie pracy } \\
\text { i czasowe osiedlanie } \\
\text { się w Polsce }\end{array}$ & $\begin{array}{c}\text { Stopień } 3 \\
\text { - uzyskiwanie } \\
\text { polskiego } \\
\text { obywatelstwa }\end{array}$ & $\begin{array}{l}\text { Stopień } 4 \\
\text { - osiedlenie } \\
\text { się na stałe } \\
\text { w Polsce }\end{array}$ & \\
\hline 26 & 179 & 274 & 268 & 747 \\
\hline
\end{tabular}

Źródło: J. Błuszkowski, Stereotypy narodowe w świadomości Polaków: studium socjologiczno-politologiczne, Warszawa 2003, s. 215.

7 J. Błuszkowski, Stereotypy narodowe w świadomości Polaków: studium socjologiczno-politologiczne, Warszawa 2003, s. 120.

$8 \quad$ Ibidem, s. 215.

9 Ibidem. 
W trzeciej części dotyczącej wymiaru partycypacyjnego można zaobserwować, iż Polacy chętnie odwiedziliby Chiny w celach turystycznych, jednak wyraźnie zarysowuje się niechęć do osiedlania się w Państwie Środka, czy też podejmowania tam pracy i otrzymywania tamtejszego obywatelstwa ${ }^{10}$.

Tabela 6. Dystans społeczny Polaków do Chińczyków - wymiar partycypacyjny

\begin{tabular}{|c|c|c|c|c|}
\hline \multicolumn{4}{|c|}{$\begin{array}{l}\text { Kontinuum wymiaru partycypacyjnego } \\
\text { Liczba odrzuceń kontaktu danego stopnia }\end{array}$} & \multirow[t]{2}{*}{$\begin{array}{l}\text { Suma } \\
\text { odrzuceń }\end{array}$} \\
\hline $\begin{array}{c}\text { Stopień } 1 \\
\text { - odwiedzenie } \\
\text { Chin przez } \\
\text { Polaków }\end{array}$ & $\begin{array}{c}\text { Stopień } 2 \\
\text { - podejmowanie } \\
\text { pracy i czasowe } \\
\text { osiedlanie się } \\
\text { w Chinach }\end{array}$ & $\begin{array}{c}\text { Stopień } 3 \\
\text { - przyjmowanie } \\
\text { obywatelstwa } \\
\text { chińskiego }\end{array}$ & $\begin{array}{c}\text { Stopień } 4 \\
\text { - osiedlenie } \\
\text { się na stałe } \\
\text { w Chinach }\end{array}$ & \\
\hline 79 & 502 & 715 & 739 & 2035 \\
\hline
\end{tabular}

Źródło: J. Błuszkowski, Stereotypy narodowe w świadomości Polaków: studium socjologiczno-politologiczne, Warszawa 2003, s. 216.

Podsumowaniem dystansu społecznego Polaków wobec innych narodów jest porządek rangowy (hierarchiczny), ustalony na podstawie zebranych informacji. Chińczycy w tym zestawieniu zajmują pozycję szesnastą, czyli dystans społeczny Polaków w stosunku do nich jest stosunkowo duży, większy skłonni są okazywać jedynie wobec Białorusinów, Turków, Żydów, Ukraińców oraz Rosjan. Jak widać, są to narody z różnych kręgów geograficznych, cywilizacyjnych i kulturowych, gdzie jedynie Białorusini, Ukraińcy i Rosjanie wydają się ze sobą najbardziej powiązani ${ }^{11}$.

Na podstawie badań profesora Błuszkowskiego widać, że Chińczyk w oczach Polaka jawi się jako zdyscyplinowany, smutny, pracowity samotnik, unikający zabaw. Mimo swojej pracowitości i zaangażowania nie opływa w dostatki, jest wręcz biedny. Dodatkowo, będąc tradycjonalistą wierzącym w zabobony, wydaje się wręcz osobnikiem zacofanym. Do tego dochodzi jego fanatyczna wręcz lojalność względem ojczyzny, która dopełnia obrazu najczęściej wymienianych przez respondentów cech, jakimi charakteryzują się Chińczycy. Nie dziwne więc, że Polacy starają się zachowywać dystans w stosunku do Chińczyków i niezbyt przychylnie patrzą na zacieśnianie więzów towarzyskich, rodzinnych czy pracowniczych. Dopuszczają za to możliwość odwiedzin w celach turystycznych zarówno Polski przez Chińczyków, jak i Chin przez Polaków.

$10 \quad$ Ibidem, s. 216.

11 Ibidem, s. 219. 


\section{Stereotyp Chińczyka - wynik ankiety własnej}

Ponieważ obraz Chińczyka wyłoniony w kompleksowych badaniach prowadzonych przez Jana Błuszkowskiego dotyczył lat 1999-2002, postanowiłam przygotować krótką ankietę, która pomogłaby mi uzyskać informację na temat tego, jak obecnie postrzegany jest obywatel Państwa Środka (ankieta przeprowadzona w 2012 roku). Przede wszystkim interesowało mnie, czy uzyskam wynik podobny do tego z badań CBOS i tego, na który wskazują badania Jana Błuszkowskiego. Kluczowe było także pytanie: co wpływa na kształtowanie się opinii Polaków na temat Chińczyków? W tym celu ułożyłam zestaw pytań dotyczących Chin i ich mieszkańców. Ankieta była anonimowa i polegała na podaniu pierwszych skojarzeń, jakie pojawią się po przeczytaniu pytania (pytania otwarte, przy których można było podać kilka określeń). Kwestionariusze rozdałam znajomym reprezentującym różne grupy wiekowe i poziomy wykształcenia. Otrzymałam 40 wypełnionych ankiet, na podstawie których spróbowałam stworzyć stereotypowy obraz Chińczyka.

$\mathrm{Na}$ ankietę odpowiedziało 40 osób. Wśród nich 77\% stanowiły kobiety, a tylko 23\% mężczyźni. Najliczniejszą grupą wiekową, która zdecydowała się wziąć udział w badaniu byli 20-31-latkowie (45\%), zaś najmniej liczną 41-50-latkowie (tylko 3\%). Również osoby mieszkające w miastach powyżej 200 tysięcy mieszkańców (równo 50\% ankietowanych) oraz osoby z wyższym wykształceniem (43\%) miały zdecydowaną przewagę. Spośród wszystkich ankietowanych (z grupy czterdziestoosobowej) 78\% przyznało, że nie zna osobiście żadnego Chińczyka, a tylko 22\% potwierdziło, iż miało w swoim życiu do czynienia z przedstawicielami Państwa Środka. Pytanie to było właściwie kluczowe, gdyż stereotyp opiera się na naszych osądach, na tym obrazie, który mamy w swoim umyśle, a który powstaje na długo przedtem, zanim osobiście zweryfikujemy jego prawdziwość. Jest dziedzictwem i bagażem otrzymanym $\mathrm{w}$ procesie socjalizacji.

Wiele odpowiedzi otrzymałam na pytanie: „Z czym kojarzy się słowo Chińczyk?” Jednak i tu wyraźnie widać sformułowania używane najczęściej. Jako najpopularniejsze skojarzenia podawano: ryż oraz osobę o małych, skośnych oczach, ubraną w strój à la pidżama, w spiczastym kapeluszu i mówiącą dziwnym językiem (po pięć osób wskazało każde z tych porównań).

Przy pytaniu dotyczącym podania synonimów dla słowa „Chińczyk”, również pojawiło się wiele odpowiedzi, ale tu wyraźnie na prowadzenie wysunęło się jedno z niezbyt miłych określeń: „żółtek”, odnoszące się do koloru skóry - podało je 17 osób, czyli prawie połowa z ankietowanych. Na drugim miejscu uplasowały się „Azjata” oraz „skośnooki” - po 10 głosów, a na trzeciej 
pozycji pod względem popularności znalazł się również niezbyt mile brzmiący "Chinol” (pięć osób).

Ciekawie przedstawia się sytuacja w punkcie, w którym należało dokończyć rozpoczęte zdanie "Chińczycy to...”. Tu najpopularniejszą odpowiedzią było "bardzo pracowity naród, pracowici ludzie” - 10 osób. Wśród kolejnych określeń wskazywanych przez respondentów (siedem osób tak dokończyło zdanie) pojawiło się „mali ludzie”, zaś sześć osób podało „najliczniejszy naród na świecie, liczny naród”. Cztery osoby wskazały, że jest to „narodowość zamieszkująca Chiny", zaś po trzy osoby przyznały, że Chińczycy to osoby spokojne oraz zdyscyplinowane. Dwoje ankietowanych uznało Chińczyków za bardzo inteligentnych ludzi ze swoją kulturą i zwyczajami.

Kolejne pytanie dotyczyło wyglądu Chińczyka i jego charakterystycznych cech. Zdecydowana większość ankietowanych jako takowe wskazała „skośne oczy” (13 osób), „żółtą skórę” (11 osób) oraz niski wzrost (dziewięć osób).

Ciekawe odpowiedzi uzyskałam na pytanie: „Kto jest Chińczykiem? Jaki warunek trzeba spełniać, aby być Chińczykiem?". Prawie połowa ankietowanych (19 osób) oświadczyła, iż trzeba się urodzić w Chinach. Dziesięć osób uważa, że trzeba mieć rodzica Chińczyka, a osiem osób, iż należy być obywatelem Chin. Jednak pojawiały się także odpowiedzi, że wystarczy mieć żółtą skórę (pięć osób), skośne oczy (cztery osoby), czy też znać kulturę, mieć chińskie pochodzenie, posiadać typowo chińską urodę i korzenie, mówić i pisać po chińsku (dwie osoby). Jeden $\mathrm{z}$ ankietowanych jako cechę decydującą o tym, że ktoś jest Chińczykiem podał fakt urodzenia się w Pekinie (tak, jakby urodzenie się w innych częściach Chin nie gwarantowało bycia Chińczykiem).

Jako najsłynniejszego Chińczyka ankietowani wskazali Jackiego Chana (15 osób), na drugim zaś miejscu uplasował się Mao, otrzymując jedenaście głosów. Pozycję trzecią z pięcioma głosami zajął Bruce Lee. Konfucjusz i Jet Li uplasowali się na pozycji czwartej z trzema głosami każdy.

Według ankietowanych, Chińczycy przede wszystkim słyną z „plantacji ryżu”, „pracowitości” oraz z „Wielkiego Muru” - te odpowiedzi podało po osiem osób. Siedem osób jest zgodnych co do tego, iż Chińczycy słyną „z podróbek”, a sześć osób wskazuje jako cechę charakterystyczną masową, tanią produkcję.

Przedmiotem, który nieodmiennie kojarzy się z Chińczykami są pałeczki do ryżu, wymienione przez zdecydowaną większość ankietowanych (16 osób). Porcelanę wskazały cztery osoby, zaś po trzy osoby wymieniły Wielki Mur, podróbkę iPhone’a oraz spiczasty kapelusz.

Szczególnie interesująco wypada odpowiedź na pytanie: „Za co cenisz Chińczyków?”. Zdecydowana większość (14 osób) przyznała, że za pracowitość, pozostawiając inne odpowiedzi daleko w tyle. Pięć osób z ankietowanej czterdziestoosobowej grupy oświadczyło, że nie podziwia Chińczyków, zaś cztery osoby 
cenią chińską kulturę. Dość zabawnie zabrzmiały odpowiedzi: „za to, że jest ich tak dużo” (dwie osoby) oraz „za ryż” (także dwie osoby).

Na pytanie odnoszące się do charakteru Chińczyków, mimo iż zdecydowana większość ankietowanych nigdy nie miała do czynienia z przedstawicielami Państwa Środka, najczęściej wskazywano odpowiedź „pracowity” - 13 osób. Również „uparty” (sześć osób) i „waleczny” (pięć), a także „miły i sympatyczny" (cztery) wysuwają się przed szereg.

Zaskoczyła mnie odpowiedź na pytanie: „Czy Chińczykowi można ufać?”. Podobnie jak w poprzednim pytaniu, mimo iż ankietowani w większości przypadków nie znali osobiście żadnego Chińczyka, jednak dość zdecydowanie opowiedzieli się, iż mają zaufanie do Chińczyków. Odpowiedzi „tak” udzieliło 17 osób, „chyba tak” - trzy osoby, „Zależy od człowieka” - siedem osób.

Podobnie miała się sprawa z pytaniem: „Czy lubisz Chińczyków?”. Większość zdecydowanie potwierdziła - 23 osoby. Cztery przyznały, że nie mają nic przeciwko nim, trzy podkreśliło swój neutralny stosunek.

Prawie każdy z ankietowanych jako charakterystyczną potrawę spożywaną przez Chińczyków wskazał ryż - 34 osoby. Żadna inna odpowiedź nie zdobyła takiej popularności. Na drugim miejscu uplasowały się ryby oraz psy/szczeniaczki, jednak z zaledwie ośmioma głosami.

Niestety, większość ankietowanych nie odpowiedziała na pytanie dotyczące powiedzeń i przysłów związanych z Chinami - twierdząc, iż ich nie zna (23 osoby).

„Jak coś jest chińskie, to jest..." - w tym punkcie, polegającym na uzupełnieniu urwanego zdania, również pojawiła się odpowiedź dominująca, którą wskazało 11 osób. „Tanie” - nie miało sobie równych, jednak "tandetne” - wybrane przez siedem osób zajęło drugą pozycję tuż przed „słabej jakości” z czterema głosami.

Nie zaskakuje odpowiedź na pytanie dotyczące tego, skąd ankietowani czerpią wiedzę na temat Chin. Tu Internet nie miał sobie równych - 25 osób podało go jako główne źródło informacji, tuż przed książkami, które uzyskały już tylko 14 głosów. Jednak, co ciekawe, na pytanie: „Jaką informację na temat Chin czytałeś, oglądałeś ostatnio?” najwięcej było odpowiedzi: „Nie pamiętam” (16 osób) oraz „Nie słyszałem”.

$\mathrm{Na}$ pytanie dotyczące najpopularniejszego aktora chińskiego pochodzenia, więcej niż połowa ankietowanych wskazała Jackiego Chana - 24 głosy, Jet Li z pięcioma głosami i Brucéa Lee z trzema pozostali daleko w tyle. Wśród filmów wymienianych przez ankietowanych również na pierwszej pozycji uplasował się ten, w którym występuje Jackie Chan - Kowboj z Szanghaju, zaś kilkanaście innych tytułów z tym samym aktorem zajęło dalsze miejsca. Większość respondentów przyznała, że postać kreowana przez wymienionego przez nich aktora wzbudziła ich sympatię. 
Pytanie dotyczące polskich reklam związanych z tematyką chińską nie spotkało się ze zbyt dużym odzewem. Większość ankietowanych po prostu stwierdziła, że nie zna takowych (24 osoby). Po pięć osób kojarzyło reklamy sieci Plus i zupek chińskich, trzy reklamę Telekomunikacji Polskiej z Sercem i Rozumem w chińskiej aranżacji.

Podobnie sprawa przedstawiała się z dowcipami i skeczami o Chinach i Chińczykach. Tu 19 osób odpowiedziało, że nie zna, siedem nie pamiętało, jednej „nic nie przychodziło do głowy”. 13 osób zdecydowało się podzielić swoją wiedzą w tym zakresie i, jak widać, przytaczane przez nich teksty, odzwierciedlają to wszystko, co na temat Chin i Chińczyków mówili ankietowani.

1. „Prawdziwy mężczyzna musi zasadzić drzewo, wybudować dom i spłodzić syna, prawdziwy Chińczyk musi wyprodukować laptopa, tenisówki i podkoszulek".

2. "No to po szczeniaczku”.

3. „O Chińczyku, Polaku, Niemcu i Rusku. Lecą samolotem i Polak się ich pyta: - Z czego słyną wasze kraje?

Rusek: Mamy tyle terytorium, że przykryje cały świat i jeszcze go zostanie. Niemiec: Mamy tak wielką flagę, że przykryje cały świat i jeszcze jej zostanie.

Chińczyk: Mamy tyle ryżu, że przykryje cały świat i jeszcze go zostanie. Polak na to: A nasz orzeł zeżre wasz ryż, wy ${ }^{* *}$ a się na wasz kraj i podetrze się waszą flagą".

4. „Rower po chińsku - samarama”.

5. „Szpital: lekarz wyrzuca pacjenta:

- I więcej mi tu nie wracaj! - krzyczy mu na do widzenia.

- Co się stało? - pyta pielęgniarka.

- Ja go pięć lat leczę na żółtaczkę, a on dopiero teraz mówi, że jest Chińczykiem!"

6. „Tata Chińczyk, matka Japonka, a dziecko mieszaniec” - z jednoczesnym pokazywaniem na oczy.

7. „Ile pompek robi Chińczyk w minutę? - Pięć: trzy do piłki i dwie do roweru”.

8. „Trzy najpopularniejsze słowa na świecie - Made in China”.

9. Skecz Ani Mru Mru - „Nasz klient - nasz pan” x 3.

Patrząc na powyższe przykłady, wymienione przez ankietowanych, można zauważyć, że wyłania się z nich obraz Chińczyka - tego o jakim mówili respondenci w poprzednich pytaniach dotyczących wyglądu, cech charakterystycznych i temu podobnych przymiotów przynależących przedstawicielom Państwa Środka. Pracowitość Chińczyków widoczna jest w przykładzie nr 1, 7, 8. Charakterystyczna cecha wyglądu - żółta cera, skośne oczy - przykład nr 5, 6. Bieda Chińczyków - przykład nr 4. Ryż jako jeden z atrybutów Chińczyka 
- przykład nr 3. Psy jako jeden z charakterystycznych posiłków - przykład nr 2. Z kolei przykład nr 10 (skecz kabaretu Ani Mru Mru) pokazuje Chińczyka jako wiecznie uśmiechniętego jegomościa, który kłania się na każdym kroku i wydaje się uniżony w stosunku do klienta.

Porównując wyniki badań profesora Błuszkowskiego z wynikami krótkiej ankiety przygotowanej przeze mnie, można zauważyć, iż cztery cechy powtarzają się w każdym z badań, a cecha pracowity ma prawie jednakową, równie wysoką procentowo ilość odpowiedzi, co świadczy, iż Chińczycy bezsprzecznie postrzegani są jako osoby bardzo pracowite - jest to wręcz ich cecha charakterystyczna, która nie uległa zmianie. Również określenia honorowy, zdyscyplinowany i patriota wyróżniają się w obu badaniach. Najlepiej przedstawi to tabelka zestawiająca wyniki obu badań. Pogrubioną czcionką zaznaczone zostały te same odpowiedzi.

Tabela 7. Cechy Chińczyków w oczach społeczeństwa polskiego

\begin{tabular}{|c|c|}
\hline $\begin{array}{c}\text { Obraz Chińczyka w badaniach } \\
\text { Błuszkowskiego }\end{array}$ & $\begin{array}{l}\text { Obraz Chińczyka - na podstawie } \\
\text { własnej ankiety badawczej }\end{array}$ \\
\hline $\begin{array}{l}\mathbf{3 3 , 3} \% \text { pracowity } \\
21,1 \% \text { biedny } \\
\mathbf{1 1 , 7 \%} \text { fanatyczny } \\
\mathbf{1 0 , 7 \%} \text { zdyscyplinowany } \\
\text { 10,3\% lojalny obywatel } \\
\text { 8,9\% skromny } \\
\text { 8,8\% tradycjonalistyczny } \\
\text { 8,1\% zacofany } \\
\mathbf{8 \%} \text { honorowy } \\
\text { 7,6\% ceniący życie rodzinne } \\
\text { 6, 9\% przesądny } \\
\text { 6,8\% zamknięty } \\
\text { 6,8\% konserwatywny } \\
\mathbf{6 , 7 \%} \text { patriota } \\
\text { 6,6\% oszczędny } \\
\text { 6,2 \% smutny } \\
\text { 5\% brudny }\end{array}$ & 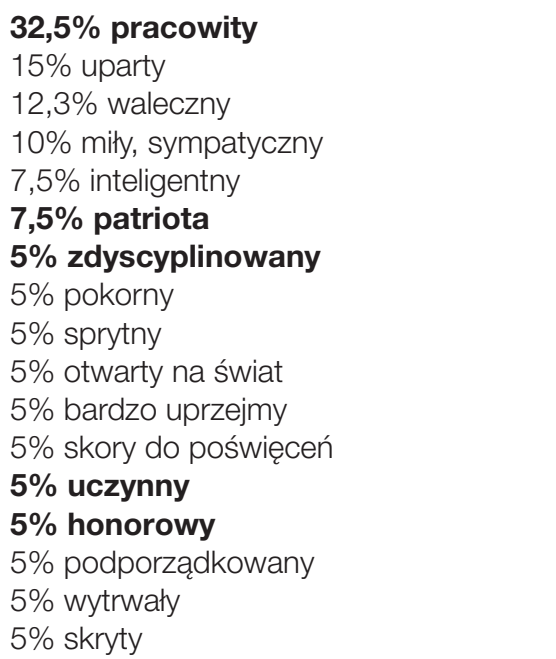 \\
\hline
\end{tabular}

Źródło: opracowanie własne.

Moi ankietowani byli zgodni co do tego, że Chińczycy charakteryzują się żółtą skórą, skośnymi oczami i niskim wzrostem. Określali ich jako najliczniejszy naród na świecie, który żywi się ryżem, rybami i psami. Pałeczki do ryżu to atrybut Chińczyka. Chińczycy kojarzą się Polakom także z tandetnymi rzeczami produkowanymi na masową skalę oraz z podróbkami znanych marek. Jackie Chan zaś jest ambasadorem wszystkich Chińczyków i z nim kojarzy się przedstawicieli Państwa Środka. 


\title{
Podsumowanie
}

Reasumując - stereotypowy obraz Chin i Chińczyków, jaki obecnie mamy w swoich głowach, a który w dużej mierze opieramy na przekazach medialnych (głównie filmy z Jackie Chanem), jest $\mathrm{z}$ reguły pozytywny i, z racji odległości dzielącej nasze państwa, nieobciążony żadnymi historycznymi zatargami. W chwili obecnej cenimy Chińczyków za ich pracowitość, zdyscyplinowanie, honor i patriotyzm. Jednak z drugiej strony, pojawia się obawa związana z liczebnością tego narodu (ankietowani wskazywali, że to najliczniejszy naród na świecie). Jeśli są tak pracowici i jest ich bardzo dużo, to mogą zagrozić naszej uporządkowanej egzystencji (odbierając miejsca pracy, przyjmując niższe wynagrodzenie), dlatego też wolimy nie wchodzić z nimi w bliskie relacje. Bliskość kontaktów zawsze wpływa na dodanie negatywnych emocji do obrazu innego narodu, co jest niejako funkcją obronną naszego poczucia narodowego.

\section{Bibliografia}

Berting J., Villain-Gandossi Ch., Rola $i$ znaczenie stereotypów narodowych w stosunkach międzynarodowych: podejście interdyscyplinarne, [w:] Narody i stereotypy, T. Walas (red.), Kraków 1995, s. 13-30.

Błuszkowski J., Stereotypy a tożsamość narodowa, Warszawa 2005.

Błuszkowski J., Stereotypy narodowe $w$ świadomości Polaków: studium socjologiczno-politologiczne, Warszawa 2003.

IT Media, Firmin Didot, http://www.mojefonty.pl/firmin-didot/ [dostęp: 20.01.2013].

Lippmann W., Public Opinion, New York 1922.

Stosunek Polaków do innych narodów, Komunikat z badań, CBOS, nr 53, Warszawa 2016.

\begin{abstract}
In international relations national stereotypes play a very crucial role. Since they have an influence on our subconscious level, they also decide about our sympathy or antipathy toward individual nations. Fields, German, Russian, Chinese etc. stereotypes make us project images which are built on the vision of a nation that was inherited by us in the process of growing up in a particular cultural environment.

Based on research conducted in Poland and as well as my own research survey I will present how the eyes of Poles are presented by the Chinese
\end{abstract}

Keywords: national stereotypes, Chinese, research in Poland, image of Chinese 